\title{
Kinetic Study of Calcination of Jakura Limestone Using Power Rate Law Model
}

\author{
*K. Mu'azu, M. Abdullahi and A.S. Akuso \\ Pilot Plant Division, Research \& Development Department, \\ National Research Institute for Chemical Technology, P.M. B 1052, Zaria, Kaduna State, Nigeria. \\ [*Author for correspondence, kabirumuazu@yahoo.co.uk, Tel: +234(0)8027106787]
}

\begin{abstract}
The current demand of hydrated lime $\left[\mathrm{Ca}(\mathrm{OH})_{2}\right]$ worldwide has necessitated investigation into kinetics of calcinations of some large commercial deposits of limestone in Nigeria. The study is aimed at finding kinetic parameters for the purpose of energy saving, lime kiln design, modeling and simulation of lime kiln. In this study, kinetic of Jakura limestone calcination process using power rate law has been investigated. The Jakura limestone has percentage composition of 96.56\% of Calcium Carbonate $\left(\mathrm{CaCO}_{3}\right)$ and the results of its decomposition at different temperature between $800 \mathrm{i} 1200^{\circ} \mathrm{C}$ showed that conversion of $\mathrm{CaCO}_{3}$ to quicklime $(\mathrm{CaO})$ increased with increase in reaction temperature and reaction time. It was observed that optimum conversion time within the temperature range studied was 6 hours with maximum conversion of $91.01 \%$ achieved at $1200^{\circ} \mathrm{C}$. The calcination of Jakura limestone was also found to be first order reaction with respect to $\mathrm{CaCO}_{3}$ concentration having average regression coefficient of 0.99 . The temperature dependent terms were found using Arrhenius law and it was observed that the reaction temperature has a direct effect on the rate of reaction. The effective values of activation energy and frequency factor were all within the range of literature values and were found to be $121.708 \mathrm{~kJ} / \mathrm{mol} / \mathrm{K}$, and 2.943 respectively.
\end{abstract}

Keywords: Jakura, limestone, calcination, kinetics, power law model.

\section{INTRODUCTION}

Lime is one of the worldôs most useful industrial chemical. World production of lime grew from just under 60 million tones in 1960 to approximately 117 million tones in 2003 (Zur, 2006), with United State and China each accounting for about 20 million tone, or $18 \%$ of world output. Limestone have been ranked as the world $\hat{Q}$ most widely used chemical after petroleum and occurs in many parts of Nigeria with proven commercial deposits in Cross River, Ogun, Benue, Kwara, Sokoto and Anambra States. Others are Niger, Imo, Edo, Delta and Kogi States. The major application of quicklime is in water treatment plant, leather industry, fertilizer industry, sewage treatment plant etc. Despite proven deposits of limestone in Nigeria in a commercial quantity the production of lime is still on a very low level, partly due to enormous amount of energy required during the calcinations reaction (Ugwu et al., 1999). Wicky and Walmsley et al. (2006) have reported that to produce 1 tone of lime, $3.16 \mathrm{GJ}$ of heat is required and the dissociation begins between $780^{\circ} \mathrm{C}$ and $1340^{\circ} \mathrm{C}$ and the temperature must be maintained throughout the reaction process according to the following equation (KirkOthmer, 1981 and Moffat et al.(2004).

$$
\mathrm{CaCO}_{3} \underset{\text { Heat }}{\longrightarrow} \mathrm{CaO}+\mathrm{CO}_{2}
$$

Energy audit conducted in a typical lime kiln (Wicky and Walmsley et al., 2006) showed that only $56.8 \%$ of the heat supplied was used to decompose $\mathrm{CaCO}_{3}$. The remaining $43.2 \%$ of the energy was irreversibly lost through kiln shell $(5.8 \%)$, flue gases (32\%), product (2\%) and miscellaneous losses (which accounts for $3.6 \%$ ).It is therefore necessary to minimize this energy loss through study of reaction parameters governing the calcination process.

Kinetic studies of different limestones have been investigated by many researchers (Dogu et al., 2001, Borgwardt et al., 1985 and Feng and Lombardo, 2002) but there has not been any reported work on that of Jakura limestone which is abundantly present in Nigeria with proven commercial deposits. For this reason, a fundamental investigation of Jakura limestone kinetics is necessary with a view to generate reliable data for energy saving, product quality, lime kiln design, optimization and modeling and also to provide basis for comparison with other limestones.

Different models can be employed to study the kinetics of limestone calcination (Sani, 2008) which includes heterogeneous model, homogeneous, intermediate model and power law model. In this investigation power law model was chosen due to its simplicity and few 
data are required without the need for several assumptions or simplifications on the parameters governing the reaction model. The model is also based on the dependence of the reaction rate on concentrations of the different species that take part in the reaction and can be verified using either integral or differential method of data analysis.

The aim of this paper is to present the kinetics of Jakura limestone calcination at various temperatures, study the effect of temperature on reaction rate constant and also to develop rate equation model governing the calcinations process of Jakura limestone.

\section{METHODOLOGY}

Material Collection and Preparation

Akura limestone was obtained from Jakura mineral exploration village in Kogi state, Nigeria. Fifty (50) samples of the limestone were size reduced to $5 \mathrm{~mm}$ and each sample weighed $20 \mathrm{~g}$. The Jakura limestone used in this study has composition of $\mathrm{CaCO}_{3}$ of $96.5 \%$ (Bello, 2005).

\section{Calcination of Limestone}

Seven (7) samples of Jakura Limestone each weighing $20 \mathrm{~g}$ were placed in a preheated oven and set the temperature to $800^{\circ} \mathrm{C}$. At interval of 1 hour, a sample was removed from the oven and weighed. The mass loss overtime in each case was recorded. The experiment was stopped when no further mass loss was recorded. Same procedure was repeated by varying the calcination temperature to $900^{\circ} \mathrm{C}$, $1000^{\circ} \mathrm{C}$ and $1200^{\circ} \mathrm{C}$ keeping weight of the limestone (20g) constant.

The percentage conversion or degree of calcination was obtained using equation (1) (Levensipel, 2006).

$X A=\left(\mathbb{1}-\frac{C A}{C A_{0}}\right)$

Where $\mathrm{XA}=$ fractional conversion of $\mathrm{CaCO}_{3}$ to $\mathrm{CaO}, \%$

$\mathrm{C}_{\mathrm{A}}=$ concentration of $\mathrm{CaCO}_{3}$ at anytimeáô wt $\mathrm{C}_{\mathrm{Ao}}=$ concentration of $\mathrm{CaCO}_{3}$ at time $=0$, wt.

\section{Determination of Reaction Order and Rate Constant}

For most reactions, the rate expression can be written as a product of temperature dependent term and composition dependent term (Coker, 2001 and Aderemi et al., 2001). Thus,

$r=F_{1}$ (Concentration) $x F_{2}$ (Temperature)

The composition dependent term can be found using either differential or integral method of analysis whereas temperature dependent terms can be found using Arrhenius law. For a simple irreversible reaction of this type,

$A \rightarrow$ Products

Following the changes in concentration of reactant $A$ and products, the rate of disappearance of A can be represented by

$r_{A}=-\frac{d C_{A}}{d t}=k C_{A}^{n}$

Where $\mathrm{r}_{\mathrm{A}}=$ rate of disappearance of $\mathrm{A}$, $\mathrm{mol} / \mathrm{dm}^{-3} \mathrm{~s}^{-1}$

$\mathrm{mol} / \mathrm{dm}^{3}$

$\mathrm{dC}_{\mathrm{A}}=$ change in concentration of $\mathrm{A}$,

$\mathrm{dt}=$ change in reaction time, $\mathrm{s}$

$\mathrm{k}=$ reaction rate constant

$\mathrm{n}=$ reaction order

For a first order irreversible unimolecular type reaction in the form of Equation (3) above $(n=1)$, the integrated form of Equation (4) is given in Equation (5).

$-\int_{C_{A n}}^{\prime A} d C_{A} / C_{A}-k \int_{0}^{t} d t$ or $-l n C_{A} / C_{A o}-k t$

In terms of fractional conversion $\mathrm{X}_{\mathrm{A}}$;

$\ln (1-X A)=-k t \quad(6)$

Where $\mathrm{k}$ is the reaction rate constant and has a unit of $\mathrm{s}^{-1}$ for $\mathrm{n}=1$.

A plot of $\quad \ln \left(1-X_{A}\right)$ against reaction time gives a straight line graph with slope equals to $\mathrm{k}$. The time required for $\mathrm{C}_{\mathrm{A}}$ to decrease to half of initial value $\left(\mathrm{C}_{\mathrm{Ao}} / 2\right)$ can be obtained from equation (7). $t_{-/ 2}=\ln 2 / k$

\section{Determination of Activation Energy and Frequency Factor}

The temperature dependence on the reaction rate constant $(\mathrm{k})$ has been found to be well represented by Arrhenius law (Sani, 2008 and Aderemi and Oludipe, 2000). Thus

$k=k_{o} e^{-\frac{E}{R T}}$

Where $k_{o}=$ known as the pre-exponential or frequency factor

$E=$ the activation energy, $\mathrm{kJ} / \mathrm{mol}$

$R=$ gas constant $=8.314 \mathrm{~kJ} / \mathrm{mol} \mathrm{K}$

$T=$ absolute temperature, $\mathrm{K}$ 
The value of $\mathrm{E}$ is a good measure of sensitivity of a given reaction to temperature changes. A plot of $l n k$ against $I / T$ yields values of $\mathrm{k}_{\mathrm{o}}$ and $\mathrm{E}$ (Levenspiel, 2006) by taking the natural logarithm of Equation (8) as shown in Equation (9).

$$
l n k=l n k_{0}-\frac{E}{R}\left(\frac{1}{T}\right)
$$

\section{RESULTS AND DISCUSSION Decomposition of Limestone}

Figure 1 presents the dissociation curve of Jakura limestone calcinations at different temperatures and reaction time. It can easily be seen that the concentration of $\mathrm{CaCO}_{3}$ decreased with time of reaction at all the temperature range studied $\left(800 \mathrm{i} 1200^{\circ} \mathrm{C}\right)$.

At $\mathrm{T}=800^{\circ} \mathrm{C}$, the change in concentration of $\mathrm{CaCO}_{3}$ with reaction time was negligible with maximum conversion of $4.79 \%$ achieved at $\mathrm{t}=6$ hours. However, between 6-7 hours there was no increased in the conversion of $\mathrm{CaO}$ in all temperature range studied. As the reaction progressed and reaction temperature increased from 800 to $900,1000,1100$ and $1200^{\circ} \mathrm{C}$, the rate of conversion of limestone to quicklime also increased with maximum conversion of $91.01 \%$ achieved at $\mathrm{t}=6$ hours.

\section{Rate Constant and Reaction Order}

Figure 2 presents a test of kinetic model of $1^{\text {st }}$ order unimolecular irreversible reaction of the type shown Figure 3 that at temperature of $800^{\circ} \mathrm{C}$, the rate of conversion of $\mathrm{CaCO}_{3}$ to $\mathrm{CaO}$ was negligible as compared with other temperatures. The dissociation of limestone begins at approximate temperature of about $800^{\circ} \mathrm{C}$ and proceeds in Equation (3) using intergral method of data analysis. Linearization of Figure 2 using least square method technique (Stroud, 2001) resulted in Figure 3.It can easily be seen that in from the outer surface of the limestone particle to the interior. As the reaction temperature increased from 800, 900, 1000, 1100 and $1200^{\circ} \mathrm{C}$, the reaction rate constant $\tilde{n} k$ ò was also found to increase as by the slope of each curve in Figure 3 and presented in Table 1.

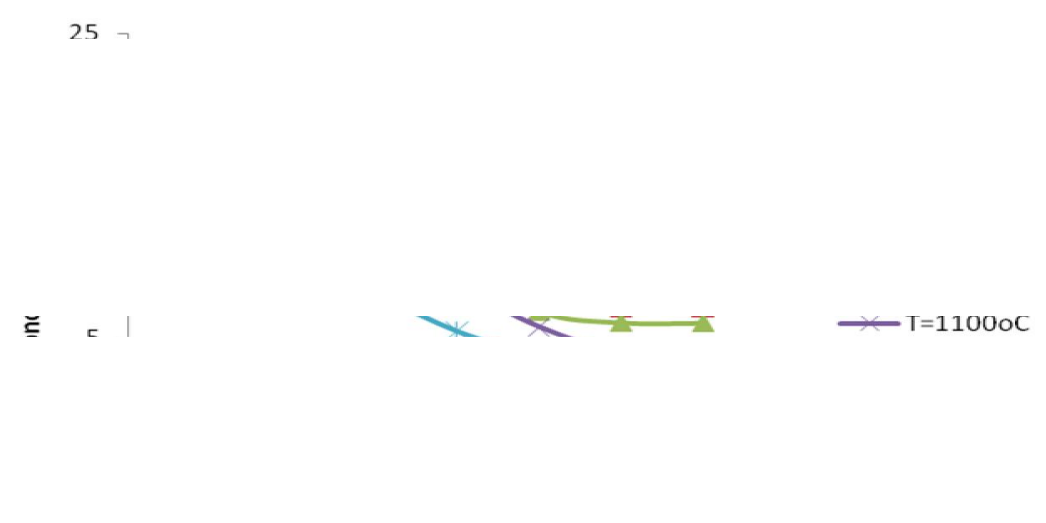

Figure 1: Effect of temperature on the decomposition of Jakura limestone

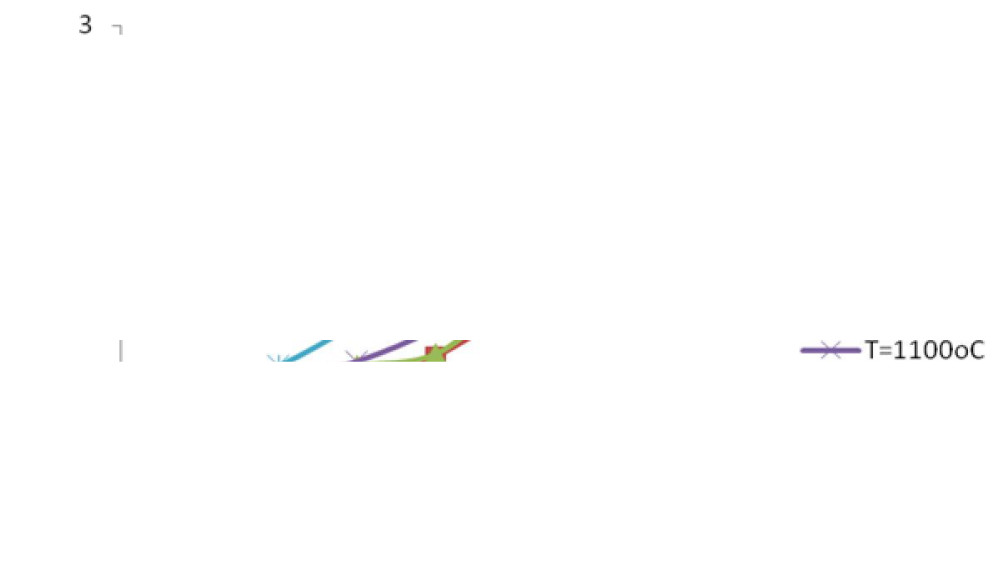

Figure 2: Effect of reaction time on conversion in case of first order kinetics 


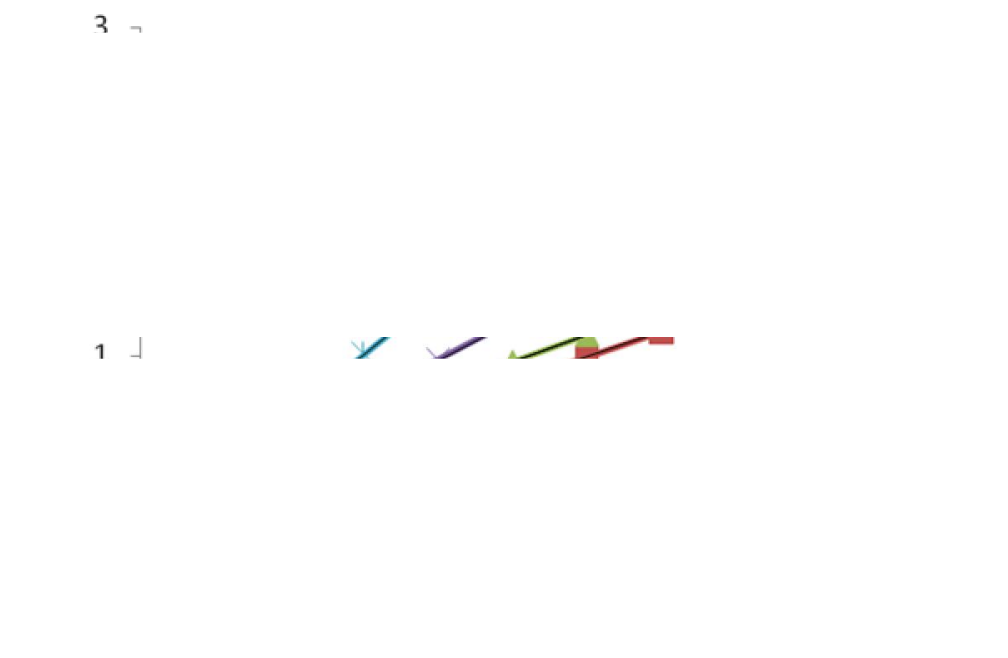

Figure 3: Linearized curve for the determination of reaction rate constant at various temperatures.

Table 1: Effect of temperature on reaction rate constant ớô

\begin{tabular}{lc}
\hline Temperature $\left({ }^{\circ} \mathrm{C}\right)$ & Rate constant $\tilde{\text { r }} k \grave{o}, \mathrm{~s}^{-1}$ \\
\hline 800 & 0.008 \\
900 & 0.152 \\
1000 & 0.163 \\
1100 & 0.236 \\
1200 & 0.368 \\
\hline
\end{tabular}

The slight increased in the values of ñkò with temperature was due to increase in porosity of limestone particle due to diffusion of $\mathrm{CO}_{2}$ from the interior to surface of the limestone particle, allowing increase in heat transfer to the interior region of the particle (Wicky and Walmsley et al, 2004). The linear relationship of Figure 3 having average regression coefficient of 1.0 $\left(\mathrm{R}^{2}=1.0\right)$ confirmed that the decomposition of Jakura limestone at temperature range studied followed a first order reaction (Levenspiel, 2001).

It was also observed that for all the temperature range studied, the increased in conversion of $\mathrm{CaO}$ after $\mathrm{t}=6$ hours was between $0.2 \mathrm{i} 0.4 \%$. These low values of conversion after $t=6$ hours were considered to be negligible and uneconomical with respect to energy input. Consequently the optimum conversion time was considered to be 6 hours. The time required to achieve $50 \%$ conversion at various temperatures were estimated using Equation (7) and found to be $4.56,4.25,2.94$ and 1.88 hours for temperatures of $900,1000,1100$ and $1200^{\circ} \mathrm{C}$, respectively.

Activation Energy and Frequency Factor The Activation Energy and Frequency Factor (temperature dependent terms) were estimated from the plot of $\operatorname{lnk}$ versus $1 / T$ as shown in Figure 4.The linear relationship in this graph confirmed that heat transfer is the rate controlling mechanism in the decomposition of limestone. The Activation Energy was found to be $121.708 \mathrm{~kJ} / \mathrm{mol}$ compared to literature values of $110-200 \mathrm{~kJ} / \mathrm{mol}$ and the frequency factor was 2.943.The value of Activation Energy obtained for Jakura limestone $\left(\mathrm{E}_{\mathrm{a}}=121.708 \mathrm{~kJ} / \mathrm{mol}\right)$ which has purity of $96.5 \%$ compared favourably with Tekumi limestone $\left(E_{a}=121.766 \mathrm{~kJ} / \mathrm{mol}\right)$ which has purity of $98 \%$. The relatively high value of obtained Activation Energy in both limestone is an indication of heat transfer controlled mechanism. Combining Equation (4) and (8) yielded a complete rate equation representing calcinations process of Jakura limestone as given in Equation (10).

$$
r_{A}=2.943 e^{14.64 / T} C_{A}
$$

Equation (10) can be use to determine rate of decomposition of Jakura limestone at various concentration and reaction temperature. The equation can also be used for modeling and simulation of limestone calcinations process. 
$1 / \mathrm{T}, \mathrm{K}$

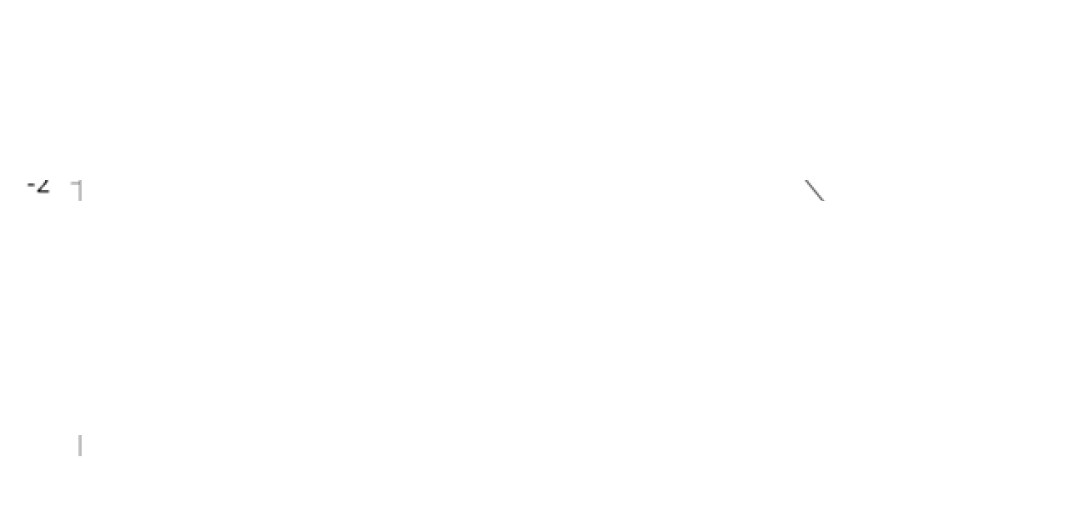

Figure 4: Dependence of reaction rate constant on temperature

\section{CONCLUSION}

The kinetic parameters for the decomposition of Jakura limestone have been determined using power law model and its rate equation has also been developed with respect to $\mathrm{CaCO}_{3}$ concentration. The optimum reaction time within the temperature range studied was 6 hours and maximum conversion of $91.01 \%$ was achieved at $\mathrm{T}=1200^{\circ} \mathrm{C}$. The value of Activation Energy obtained agreed closely with the literature value and that of Tekumi limestone.

\section{REFERENCES}

Aderemi, B.O., Oloro, E.F., Joseph, D. and Oludipe, J. (2001). Kinetics of dealumination of Kankara kaolin clay. Niger. J. Engineering 9(1): 40 ï 44.

Aderemi, B.O. and Oludipe, J.O. (2000). Dealumination of Kankara kaolin clay $\ddot{i}$ Development of governing rate equation. Niger. J. Engineering 8(2): 22 ï 30.

Bello, I.A. (2005). Improvement of performance vertical shalft lime kiln. M.Sc Thesis, Ahmadu Bello University, Zaria, Nigeria (Unpublished).

Borgwadt, R. (1985). Calcination of kinetics and surface area of dispersed limestone particles. The Chem. Engineering $J$. 31(1): 103-111.

Coker, A.K. (2001). Modeling of Chemical Kinetics and Reactor Design, Gulp professional publishing, New Delhi, India. pp. 111 ï 1150.

Dogu, G. and Ar, I. (2001), Calcination kinetics of high purity limestone. The Chem. Engineering $J$. 83(2).

Feng, K. and Lombardo, S. (2002), Kinetics Analysis from Dilatometry and mass spectrometry measurements of the decomposition and sintering of calcium carbonate. J. Ceramic Process. Res. 3(3): 101-108.

Kirk-Othmer, (1981). Encyclopedia of chemical technology, $3^{\text {rd }}$ edition, vol. 14 , p. 361 , John Wiley and Sons.

Levensipel, O. (2006). Chemical reaction engineering, $3^{\text {rd }}$ edition, pp 41 ï 50, John Wiley and Sons.

Moffat, W. and Walmsley, M.R.W. (2004). Improving energy efficiency of a lime kiln. Proceedings of Joint SCENZ/FEANZ/SMNZI conference, pp 17 ï 24, Hamilton.

Sani, Y.M. (2008). Determination of an empirical kinetic parameter for the decomposion of Alum from Kankara kaolin. M.Sc. Thesis, Ahmadu Bello University Zaria, Nigeria. Pp 25 ï 35 (Unpublished).

Stroud, K.A. (2001). Engineering Mathematics, Palgrave publishing, $5^{\text {th }}$ edition, New York. pp. 736 ï 742.

Ugwu, J.O., Gabriel, J.B. and Bello, J.O (1999). Production of lime using locally designed lime kiln. National Research Institute for Chemical Technology bi-annually bulletin, 1(1): 9 ï 10.

Wicky, M. and Walmsley, M.R. (2006). Understanding lime calcination kinetics for energy cost reduction. Paper presented at the $59^{\text {th }}$ Appita Conference, Auckland, New Zealand.

Zur, E.A. (2006), Dynamic Process Simulation of lime stone calcinations in normal shaft kilns. Ph.D. Dissertation, University Magdeburg, Republic of Germany. 